\title{
GLOBALIZATION AND NEW OPPORTUNITIES FOR GEORGIA
}

\section{SHOTA VESHAPIDZE}

\author{
Doctor of Economic Sciences, Associate Professor \\ Ivane Javakhishvili Tbilisi State University \\ Academician of the Georgian Academy \\ of Economic Sciences, Georgia \\ shota.veshapidze@tsu.ge
}

\section{KETEVAN CHIABRISHVILI}

\section{Professor}

David Aghmashenebeli National Defense Academy, Georgia

kchiabrishvili@eta.edu.ge

\author{
TAMAZ ZUBIASHVILI \\ Associate Professor \\ Ivane Javakhishvili Tbilisi State University, Georgia \\ zubtamaz@yahoo.com
}

Abstract. To define the conceptual vision of the unified development of Georgia, it is necessary to understand it as a systemic process against the background of continuous historical and civilizational progress, which emphasizes the main features of the dynamic picture from time immemorial to the present. These visions have largely led to the development of the Georgian National Security Concept. The geo-economic strategy of the country is an important part of it.

Geoeconomics as a separate science emerged in the late twentieth century and studies the interaction between the man and the space. The formation of geoeconomic science is linked to the emergence of global economic problems. A characteristic feature of modernity has been the shift of the center of gravity of the struggle against the government to the economic sphere. Problems that have been solved by force of arms for centuries are finally being solved on the basis of finances and information. Economic wars have largely replaced conventional warfare.

According to the American Scientists, Robert Blackville and Jennifer M. Harris's three-component definition, geoeconomics is the use of economic tools: to pursue and protect national interests; to achieve positive geopolitical results. Currently, in theory, geopolitical applications have seven economic instruments: trade policy, investment policy, economic and financial sanctions, cyber attacks, economic development assistance, financial and monetary policy, energy and commodity policy. They may be very different from each other, but it still makes sense to discuss them together.

Geoeconomics is an interdisciplinary subject. It allows you to study and connect the best of different subjects around one topic. Therefore, the role of geoeconomics in the preparation of undergraduate, graduate and doctoral students of economic profile is important. It allows to strengthen the interdisciplinary academic approach which will facilitate the optimal use of geo-economic instruments and the country's geo-economic potential for the interests of Georgia. The National Security Concept of Georgia, in order to realize and dispute the national interests of Georgia, analyzes the threats, risks and challenges facing Georgia and defines the main directions of Georgia's security policy. The use of geo-economic instruments plays an important role in the implementation of this policy.

KEYWORDS: GLOBAL PROBLEMS, GEOPOLITICS, FOREIGN POLICY, GLOBAL TRANSPORT, INFORMATION AND FINANCIAL TECHNOLOGIES, ECONOMIC INSTRUMENTS, GEOECONOMICS, NATIONAL INTERESTS.

For citation: Veshapidze, S., Zubiashvili, T., \& Chiabrishvili, K. (2021). Globalization And New Opportunities For Georgia. Globalization and Business. 12, 32-36. https://doi.org/10.35945/gb.2021.12.003

\section{INTRODUCTION}

In the last decade of the last century and in the following years, Georgian writers, historians, political scientists, economists, lawyers, geographers and scientists in other fields have formed interesting visions of a unified geopolitical and geoeconomic conceptual approach to the development of the country. They argued that defining a conceptual vision of Georgia's unified development requires understanding it as a systemic process in the context of continuous historical and civilizational progress, emphasizing the key features of a dynamic picture from time immemorial to the present. These visions have largely led to the development of the Georgian National Security Concept. The geo-economic strategy of the country is an important part of it. (The following papers are dedicated to this issue: Bedianashvili, 2018; Bedianashvili \& Begiashvili, 2021; Gvelesiani \& Veshapidze, 2016a, 2016b; Papava, 2015, 2016; Silagadze, 2014; Silagadze, \& Atanelishvili, 2010, 2011; Silagadze, \& Zubiashvili, 2016; Tvalchrelidze, \& Silagadze, 2013; Zoidze, 2020; Zoidze, \& Tkhilaishvili, 2021.). 
Geoeconomics as a separate science emerged in the late twentieth century and studies the interaction between man and space. In particular, its field of study is: the influence of spatial factors on the field of production and distribution of goods, the use of space for the development of economic activity. Geoeconomics conveys the economic reality as it is possible and should be in accordance with the peculiarities of space and by what methods to achieve this. If geopolitics views neighboring countries as potential enemies, then geoeconomics sees them as potential partners. If geopolitics works on national security problems, then geoeconomics works on development problems.

\section{GENERAL ANALYSIS}

The formation of geoeconomic science is linked to the emergence of global economic problems. Continuous struggles, contradictions and crises for the existence of society are constant processes accompanying the development of humanity. In order for global problems to arise on their soil, it was necessary, firstly, to increase them to a planetary scale, and secondly, to make them understood by the world community as problems that need to be solved and which can be solved by existing means. (The following papers are dedicated to this issue: Dollfus, 2000; Ismailov \& Papava, 2012; Kozak, et al., 2017; Mekvabishvili, 2016, 2018; Movsesian, \& Ognivtsev, 2003; Shengelia, 2016; Sintserov, 2000.).

At the end of the 19th century, the world felt like a whole, and the world community began to understand global problems. The world was gradually becoming truly global. From 1850 to 1914, the Earth's population increased a total of 1.5 times, and world trade turnover - 10 times. The share of foreign trade in the GDP of developed countries doubled.

Along with the export of goods, the export of capital also began to develop rapidly. The volume of foreign direct investment doubled in 1900-1913. International migration acquired enormous proportions. By 1914, 22\% of the Canadian population, $30 \%$ of the Argentine population, and more than $26 \%$ of the New Zealanders were a new generation of immigrants. US-born workers made up less than half of the country's entire proletariat.

The transportation system had virtually covered the whole world. Planetary transport unity was impressively portrayed in Jules Verne's famous novel, 80 Days Around the Earth. By 1900, virtually every region of the earth was connected by telegraph. About $89 \%$ of the world's population lived in countries with convertible currencies. Thus, at a certain technological level, global transport, information and financial technologies already existed at that time.

Londoners could order by phone ... various goods from all over the world ... they could risk their condition (property) if they invested money in natural resources and enterprises anywhere on earth. He was provided with cheap, comfortable and unobstructed travel to any country and natural zone ... but, most importantly, he considered such a situation to be natural, unchanging and constant. The internationalization of public and economic life was absolute (Keynes, 2017). John
Maynard Keynes wrote with regret in the 1920s, when the global world fell as a result of the First World War and the political revolution.

Why did globalization, which began about a century ago, suffer such devastating failure? After the war and the revolutions of 1914-1922, the global world disappeared. Countries are separated from each other by strict regimes and customs barriers. The share of foreign trade and capital outflows in the GDP of developed countries declined sharply. The tendency to reduce them seemed so long and universal that it was formed in the form of economic law - the "decreasing importance of international trade."

Until the 60s, nothing was said about the new wave of globalization. In 1963, the share of international trade in the world economy was one third less than in 1913. Since then the steps of globalization had been increasing. The 70s are characterized by the formation of mega-economy as a single economic organism. Modern globalization is very different from its historical predecessor, and this gives us hope that the global problems that have arisen today can be successfully resolved peacefully.

In the second half of the twentieth century, humanity was able to overcome the habit of resolving world conflicts by military means. It repeatedly stood on the brink of nuclear war, but a sense of self-preservation always prevailed over the thirst for power and rapid victory. Scientists made impressive and indisputable calculations that show that even one, even the first rocket-propelled grenade launcher from either side of the conflict would be quite sufficient for the emergence of a universal "nuclear winter". No matter where the rockets hit, they create a cloud of dust and soot from burned cities and other objects that will cover the sun for several years, the temperature will drop to minus all over the earth and humanity will practically disappear. The discovery of the most destructive weapons has freed mankind from world wars.

Unlike the globalization of the early twentieth century, the early twentieth century already has sufficient forces for the peaceful resolution of major global problems. The advent of new individual weapons has greatly complicated states' fights against insurgents and terrorists. Rebellious countries and terrorist groups were opposed by supranational anti-terrorist organizations.

A characteristic feature of modernity has been the shift of the center of gravity of the realization and protection of national interests to the economic sphere. Problems that had been solved by force of arms for centuries are finally being solved on the basis of finances and information. Economic wars have largely replaced conventional warfare. The power that dominated the world through the use of military force is manifested today in the power of finance, banks and TNCs. It turned out that states that throughout history have waged endless wars to conquer territories and resources to gain strength and power are no longer the only source of elite groups and nations. The same goals can be achieved much more successfully through economic expansion by TNCs. Therefore, perhaps it is only necessary to welcome the fact that the struggle for markets has shifted from a military-political to a tough but at least bloodless economic sphere. 
The Senior Researchers at the U.S. Council on Foreign Relations, Robert Blackville and Jennifer M. Harris in their book War by Other Means: Geoeconomics and the Art of Governance, they explore the role of economic and financial instruments in modern diplomacy. They elaborated on the fundamental theoretical and practical issues of geoeconomics.

At the beginning of the book, these authors cite the words of Benjamin Constant, a Franco-Swiss politician, that "war and trade are two different ways of having the same goal, the same desire." They emphasize that the term "geoeconomics" is quite widely used today, but almost always without specification (even without a job definition at least). Some authors focus on the use of geopolitical or military force to achieve economic goals. Others define geoeconomics more broadly as "a combination of international economics, geopolitics, and strategy," or as a kind of all-encompassing phenomenon; it seems that such an explanation seems to disguise the idea more than it explains it. Others pay special attention to trade, commerce, and industrial protectionism.

In view of the above, Robert Blackville and Jennifer $M$. Harris strongly recommend the following definition of geoeconomics:

Geoeconomics - the use of economic instruments to realize and protect national interests and to achieve positive geopolitical results, as well as the consequences of economic actions of other countries for the geopolitical purposes of that country (Blackwill \& Harris, 2016, 60).

Based on this approach, geoeconomics appears as a method of analysis and as a form of government. The first aspect of this three-component definition ("Using Economic Instruments to Pursue and Protect National Interests") is consistent with the traditional notion that domestic economic strength contributes to American influence in the world - at least in theory.

Similarly, the last aspect of the definition of geoeconomics ("the consequences of the economic actions of other countries for the geopolitical purposes of a given country"), historically neglected if compared to other factors in international relations, is gaining increasing attention today. So far, the focus has been on the systemic rather than the nation-state level, in an attempt to explain how large-scale economic events, such as globalization, can affect multifaceted institutions.

Despite several important discussions in the international political economy space, the "applied" issues of force projection (demonstration) and relationship management between nation states are still ignored. In short, despite some positive developments, as American professor Alan Dobson rightly puts it, "Economic issues are still often tangled between political and diplomatic factors."

Former German Chancellor Helmut Schmidt has said that "if you limit yourself to one short sentence ... monetary and credit policy - this is foreign policy ... I still think that today it is much more than before ... it is not just domestic policy... It also determines foreign policy." (Blackwill \& Harris, 2016, 47).This is not the first time that geoeconomics has begun to influence world geopolitics, but circumstances have changed dramatically. Compared to previous periods of geoeconomic prosperity - many analysts attribute them to the first years after the war, the Marshall Plan period and the early stages of the Cold War - the world today looks completely different.

Numerous modern geoeconomic tools (say, cyberattacks) simply did not exist at the time of the Marshall. Others, such as energy policy, were used even then, but today's world landscape is fundamentally different from then, and so these tools also acquired new features. The third tools, the same development aid, function in much the same way as in earlier eras. At the same time, they attract new important players and show new dimensions.

Today - at least in theory - there are seven economic instruments for geopolitical use: trade policy, investment policy, economic and financial sanctions, cyber attacks, economic development assistance, financial and monetary policy, energy and commodity policy. Geoeconomics examines each of these instruments separately, again assessing geopolitical rather than purely economic characteristics.

They may be very different from each other, but it still makes sense to consider them together. Moreover, each instrument owns its own set of "practitioner" countries and relevant institutions, specific levers of state control and success factors, as well as a special set of external "marks" - and results for the national interests of the United States.

Geoeconomics is an interdisciplinary subject. It allows you to study and connect the best achievements of different subjects around one topic. The subject of geoeconomics is related to other subjects such as: geopolitics, economics, economic geography, world economy, international economy, international finance, international economics, international economic relations, international economic security, regional economy, political economy and others.

The role of geoeconomics in the preparation of undergraduate, graduate and doctoral students of economic profile is important. It allows to strengthen the interdisciplinary academic approach, which will facilitate the optimal use of geo-economic instruments and the country's geo-economic potential for the interests of Georgia.

The concept of national security of Georgia defines the threats, risks and challenges facing Georgia. According to the concept, the national interests of Georgia are: ensuring sovereignty and territorial integrity; Developing state institutions and strengthening democracy; Developing an effective national security system; Strengthening national unity and civic consent; European and Euro-Atlantic integration; Ensuring stable long-term growth of the economy; Ensuring energy security; Ensuring regional stability; Strengthening Georgia's transit function; Ensuring ecological security of Georgia and the region; Ensuring civic integration and national and cultural identity; Strengthening cyber security; Ensuring demographic security; Relations with Diasporas. (The following papers are dedicated to this issue: Shengeia, 2015; Silagadze, et al., 2016; Veshapidze \& Zubiashvili, 2020; Veshapidze, et al., 2016; Veshapidze, 2020; Veshapidze, \& Mchedlishvili, 2020; Veshapidze, et al., 2021; Veshapidze \& Zoidze, 2021; Zubiashvili, 2012; Zubiashvili \& Veshapidze, 2019; Georgian National Security Concept, 2020).

The National Security Concept of Georgia, in order to re- 
alize and dispute the national interests of Georgia, analyzes the threats, risks and challenges facing Georgia and defines the main directions of Georgia's security policy. The use of geo-economic instruments plays an important role in the implementation of this policy.

\section{CONCLUSION}

Analysis of the development history of Georgia in the geo-economic context presents the geo-economic challenges of the country. It is important that Georgia is a maritime state. Georgia, which holds the key to the Caucasus Gate, is the maingate for Western countries to reach the Caspian Sea. The interests of the United States, other strategic and traditional partners, and transnational corporations are important.

Georgia had historically been inhabited by peoples of many nationalities and religions. Consequently, one of the most important directions of the current national policy of the country should be the effective adaptation to the reali- ties of a multinational, multi-confessional state. The solution to this problem involves establishing dialogue between religions, taking into account the national, cultural and religious needs of minorities, and developing a new approach.

After the restoration of state independence, the country's geopolitical potential increased as a result of Georgia's strong, strengthened orientation towards Euro-Atlantic values. This is mainly due to the Caspian energy reserves, and their transportation plans. This is a key factor for the country, as well as the fact that Georgia is becoming the center of interests of various world powers. The country will play an important role in pursuing Euro-Atlantic policy in the Caucasus subregion, as well as the interests of traditional partners and other countries in the region.

It is necessary to pay constant attention to economic ties with Russia. Severe relations with Russia significantly hinder the faster development of the Georgian economy. Only with the help of international strategic partners it can be possible to move to a mode of mutual understanding and dialogue between countries. This is important for fulfilling the state tasks of the country.

\section{REFERENCES:}

Bedianashvili, G. (2018). Knowledge Economy, Entrepreneurial Activity and Culture Factor in Modern Conditions of Globalization: Challenges for Georgia. Globalization and Business, (5) 32-37. https://doi.org/10.35945/gb.2018.05.004

Bedianashvili, G., \& Begiashvili, R. (2021). Global Challenges for the Tax System during the Pandemic and the Response of the Georgian Tax Administration to Covid-19. Conference Proceedings: Social Sciences for Regional Development 2020. Part I. Issues of Sociology. Daugavpils University, 5-18.

Blackwill, R. D., \& Harris, J. M. (2017). War by Other Means, Geoeconomics and Statecraft. (In Russion).

Dollfus, O. (2000). The world-system. Geopolitics, 5(2), 52-66.

Georgian National Security Concept (2020). Available at: https://mfa.gov.ge/MainNav/ForeignPolicy/NationalSecurityConcept.aspx (accessed: 28.09.2021)

Gvelesiani, M., \& Veshapidze, Sh. (2016a). European Values: What Can We Implement from Them and How Can We Implement Them in Georgia. Globalization \& Business. (In Georgian).

Gvelesiani, M., \& Veshapidze, Sh. (2016b). Values: Limits and Contradictions. Globalization \& Business. (In Georgian).

Ismailov, E., \& Papava, V. (2012). Central Eurasia: A New Geopolitical Understanding. Tbilisi, Intellect Publishing House. (In Georgian). Keynes, J. M. (2017). The economic Consequences of the Peace. Routledge.

Kozak, Y., Shengelia, T., \& lerokhin, S. (2017). Essentials of International finance: Questions \& Answers. Tbilisi: Publishing House Universal.

Mekvabishvili, E. (2016). Unity of Globalization and Modernization - The Modern Economic Development Paradigm. Globalization \& Business. (In Georgian).

Mekvabishvili, E. (2018). The Financial Crisis of the Globalization Era and the Economy of Georgian. Tbilisi. (In Georgian). Movsesian, A. G., \& Ognivtsev, S. B. (2003). World Economy: A Textbook. Moscow: Finances and Statistics. (In Georgian). Papava, V. (2015). Necroeconomics of Post-soviet PostIndustrialism and the Model of Economic Development of Georgia and Russia. Papava, V. (2016). Globalization, the European Union and Georgia. Globalization \& Business. (In Georgian).

Shengelia, T. (2015). Terrorism, as Socio-Political Phenomenon and Impeding Factor for Global Business. Ecoforum Journal, 4 (2). Shengelia, T. (2016). Corruption on as Social Phenomenon and Determinant of Global Business. Globalization \& Business. (In Georgian).

Silagadze, A. (2014). Integration Economic Indicators of the EU and Some Issues of Development of Post-Soviet CountriesNew Associate Members of the EU. Revista Moldovenească de Drept Internațional și Relații Internaționale. 3, 78-83.

Silagadze, A., \& Atanelishvili T. (2011). The Potential of the Agrarian Sector of Georgia-Priorities of the Sustainable Development of Agriculture. Tbilisi, TSU, 418-419.

Silagadze, A., \& Atanelishvili, T. (2010). Some Questions of Economic Doctrines in Georgia. Moscow, Vzfei, 51.

Silagadze, A., \& Zubiashvili, T. (2016). Georgiass Economy against the Background of the Associate Agreement with the European Union. International Journal of Business and Management Studies, 5(2), 533-540. 
Silagadze, A., Tvalchrelidze, A., Zubiashvili, \& T., Atanelishvili, T. (2016). Aspects of Chinass economic Development. Ecoforum 5 (1). Sintserov, L. M. (2000). Long Waves of Global Integration. Mirovaya Ekonomika I Mezhdunarodnyye Otnosheniya, (5), 56-64. Tvalchrelidze, A., \& Silagadze, A. (2013). Macroeconomic Model for Oil-Exporting Countries. Central Asia and the Caucasus, 14(4), 118-144.

Veshapidze, Sh. (2020). Religion and National Values in Georgia. In World Economy and International Economic Relations, 3, $33-36$.

Veshapidze, Sh., \& Mchedlishvili, Z. (2020). From Ilia Chavchavadze's Economic Views: Competition, Private Property and International Trade. Ecoforum Journal, 9(2).

Veshapidze, Sh., \& Zoidze, G. (2021). Institutional Evolution of Higher Education in Georgia. The New Economist, 16(2), 1-1. DOI: 10.26399/meip.2(69).2020.10/g.zoidze. (In Georgian).

Veshapidze, Sh., \& Zubiashvili, T. (2020). About the Origins of Modern Geoeconomic Foundations of Georgia. Ecoforum Journal, 9(2).

Veshapidze, Sh., Chiabrishvili, K., Zubiashvili, T., \& Zoidze, G. (2021). On The Relationship between Education and Economic Security. Ecoforum Journal, 10(3).

Veshapidze, Sh., Darbaidze, M., \& Beridze, T. (2016). Euro-Atlantic Values: What Tie up Us.

Zoidze, G. (2020). Georgian Agro-Sphere Development Priorities and Ways of Carrying out Some Improvements. Myśl Ekonomiczna i Polityczna, 2 (69), 55-71.

Zoidze, G., \& Tkhilaishvili, G. (2021). Prospects of Intermodal Transportation and Logistics Channels Development for Georgia. In Proceedings of 25th International Scientific Conference. Transport Means.

Zubiashvili, T. (2012). Educational and Labor Emigration of Youth from Georgia. The book: Youth Employment: Challenges and Opportunities. The West University of Timisoara, Romania. Eurostampa, 317-327.

Zubiashvili, T., \& Veshapidze, Sh. (2019). Labour Emigration and Employment in Georgia. Humanities and Social Sciences Review, 9(01), 127-136. 